Animal Health Research Institute,

Alex. Branch.

\title{
EPIDEMIOLOGICAL STUDIES ON SALMONELLOSIS IN BROILER CHICKEN FARMS IN ALEXANDRIA GOVERNORATE
}

(With 3 Tables)

By

F.A. EL-SHABOURY and OLA A.A. BASHA

(Received at 16/3/2009)

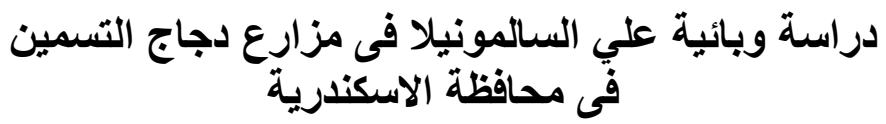

فتح الله على الشابورى ، علا عبد العزيز باثـا

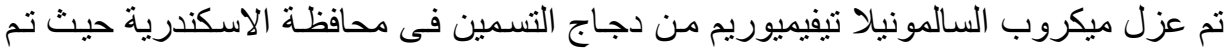

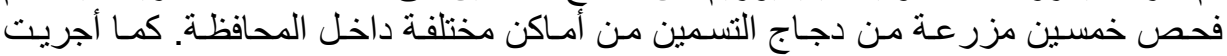

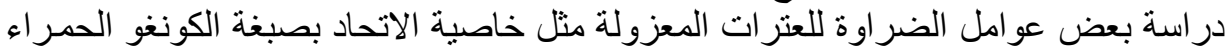

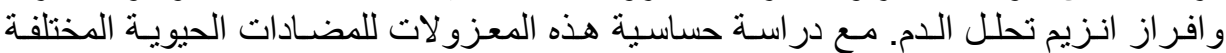

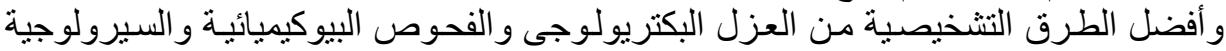

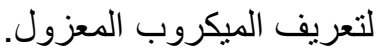

\section{SUMMARY}

A survey on Salmonella infection was carried out on 5o broiler chicken farms located at Alexandria Governorate. A total of 5 Salmonella isolates were isolated and serotyped using different selective enriched media for isolation and a variety of biochemical and serological tests for identification. The in-vetro sensitivity test revealed that Neomycin and Ceftiofur gave the heighest activity against Salmonella isolates. On the other hand, Salmonella typhimurium isolates showed resistance against Erythromycin, Amoxycillin and Ampicillin. Moreover, Salmonella isolates were tested for their virulence using Congo red binding test and ability to produce hemolysin.

Key words: Broilers, salmonellosis, S.typhimurium. 


\section{INTRODUCTION}

Salmonella is one of the most important microorganisms that cause diseases in man and animals and among common causes implicated in outbreaks of food borne infectious disease around the world, (Abou-Zeed et al., 2000). Salmonellae have a wide host range, including human, animals and birds (Duce et al., 1991). Poultry have been implicated as a major source of Salmonella contaminated food products as poultry eggs or meat that cause human salmonellosis (Tauxe, 1991 and Humaphrey, 1999). Salmonella pullorum has a long history of causing economically significant illness and mortality in young commercial chickens (Snoeyenbos, 1991). Salmonella typhimuruim found to be the main cause of Salmonella in human and animals (Groisman et al., 1989). Much more, Salmonella entritidis, only arose to its predominant position in man and poultry in the mid-1980s as a result of vertical and horizontal transmission within and between large poultry organization in many parts of the world (Hartung, 1992). Sensitivity of isolation of these organisms by culture depends on various factors including the method used for collecting the sample, the amount of sample analyzed and seasonal variation in shedding the organism (Cohen et al., 1994). The growth inhibition by other bacteria can be a particular problem, especially with faecal samples which are often heavely contaminated with other microorganisms, moreover, in chronic Salmonella infection in fowl, Salmonella organisms are excreted only intermittently in faeces. Standerd procedures for isolation and identification of Salmonella using growth media are slow and often these tests fail to detect bacteria that may be present for that, numerous schemes for pre enrichment, direct enrichment and secondary enrichment have been examined for recovering and isolating Salmonella from meat, poultry and enviroment (Tate et al., 1990). There is a need for Salmonella testing methods that provide more rapidly and sensitivity results. These rapid methods should be robust and reliable and have a specificity that minimize false positive results. (Blackburn, 1993).

Plasmid analysis has a great effect as an epidemiological tool in an outbreak of salmonellosis (Kapperud et al., 1989). More, plasmid analysis is relatively simple to perform, does not require aspecialized reference laboratory and can be accomplished in a short period of time and not expensive (Mayer, 1988)

The purpose of this work was designed to study the incidence of Salmonella infections in broiler chicken farms by using different 
methods of enrichment for isolation and applying biochemical and serological methods for identification, Moreover study some virulence factors for Salmonella microorganisms and finally isolated Salmonella were tested for antimicrobial drug susceptibility.

\section{MATERIALS and METHODS}

\section{1 - Bacteriological isolation:}

A total of 50 broiler chicken farms of different ages at different localities in Alexandria Governorate were subjected for bacteriological studies, from each flock 5-7 live and freshly dead chicken aged from 1-5 week were taken for isolation and identification of Salmonella using enriched media as "Selenite F broth and Tetrathionate brilliant green broth" incubated at $37-42^{\circ} \mathrm{C}$ for $24-48 \mathrm{~h}$. (Oxoid 1987) and delayed secondary enrichment for 5 days (Waltman et al., 1991), then cultured on MacConkey's agar, Salmonella-Shigella (SS) agar and Brillient green agar incubated at $37^{\circ} \mathrm{C}$ for $24 \mathrm{~h}$. ( Oxoid, 1987).

The suspected colonies were examined morphologically and biochemically.

\section{2 - Morphological identification:}

Purified suspected Salmonella isolates were examined morphologically as described by Cruickshank et al. (1975).

\section{3 - Biochemical identification:}

Suspected Salmonella isolates were identified biochemically using criteria of Quinn et al. (1994).

\section{4 - Serological identification:}

Cultures biochemically identified as Salmonella were typed serologically according to Kauffmann White Scheme (Kauffmann, 1972) by slide agglutination test using polyvalent "O" Salmonella antiserum. Colonies which gave positive results were similarly tested using monovalent "O" and "H" Salmonella antisera.

\section{5 - In vitro antibiotic sensitivity test:}

It was done according to Finegold and Martin (1982) using Muller Hinton agar (Oxoid) and commercial antibiotic discs (Oxoid and BBL) including Neomycin $(30 \mu \mathrm{g})$, Gentamycin $(10 \mu \mathrm{g})$, Amoxycillin (25 $\mu \mathrm{g} \mathrm{ug})$, Norfloxacin $(10 \mu \mathrm{g})$, Stryptomycin (10 $\mu \mathrm{g})$, Ampicillin (40 $\mu \mathrm{g})$, Oxytetracyclin (30ug $\mu \mathrm{g})$, Chloramphenicol $(30 \mu \mathrm{g})$, Ceftiofur $(30 \mu \mathrm{g})$, Doxycycline $(30 \mu \mathrm{g})$, and Erythromycin $(15 \mu \mathrm{g})$. 


\section{6 - Detection of virulence factors:}

1 - Congo red binding activity (Agenta et al., 1977). Salmonella strains were cultured on Congo medium. Congo red positive salmonella isolates were identified by appearance of red colonies. The reaction was best seen after 24 hours incubation at $37^{\circ} \mathrm{C}$, followed by an addition of dys at room temperature. Congo red negative Salmonella colonies did not bind the dye (white colonies).

2 - Detection of haemolysin (Tange et al., 1993). Salmonella isolates were inoculated into blood agar plates contaning 5\% sheep blood, after 24 hours of incubation at $37^{\circ} \mathrm{C}$ positive $\mathrm{B}$ - haemolysis production was indicated by clear zone of haemolysis.

\section{RESULTS}

\section{Incidence of Salmonella among broiler chicken flocks:}

Out of 50 examined broiler chicken flocks, a total of 5 suspected Salmonella isolates were recovered. These isolates were subjected to further examination by polyvalent and monovalent Salmonella antisera. Five Salmonella isolates were obtained and identified as Salmonella typhimurum. (Table 1), and the biochemical characteristics of Salmonella isolates are illustrated in Table (2). The results of drug sensitivity was studied and summarized in Table (3). which indicated that Salmonella typhimurum was found sensitive to Neomycin, Ceftiofur and Gentamycin, while it was resistant to Ampicillin, Erythromycin, Oxytetracyclin and Amoxycillin, and showed variable degrees of sensitivity against other antimicrobial agents. Regarding to virulence activity of Salmonella isolates it was found that the examined isolates were bounded with Congo red dye giving red colonies and produce Bhaemolycin on blood agar.

Table 1: Incidence of Salmonella among broiler chicken flocks.

\begin{tabular}{|c|c|c|c|c|c|}
\hline $\begin{array}{c}\text { Age of broiler } \\
\text { chickens }\end{array}$ & $\begin{array}{c}\text { No. of examined } \\
\text { flocks }\end{array}$ & $\begin{array}{c}\text { Positive } \\
\text { flocks }\end{array}$ & $\begin{array}{c}\text { No. of } \\
\text { isolates }\end{array}$ & $\begin{array}{c}\text { Serotype of } \\
\text { salmonella }\end{array}$ & Incidence (\%) \\
\hline $1^{\text {st }}$ week & 10 & 1 & 1 & S.typhimurum & 10 \\
\hline $2^{\text {nd }}$ week & 10 & 2 & 2 & S.typhimurum & 20 \\
\hline $3^{\text {rd }}$ week & 10 & 1 & 1 & S.typhimurum & 10 \\
\hline $4^{\text {th }}$ week & 10 & 1 & 1 & S.typhimurum & 10 \\
\hline $5^{\text {th }}$ week & 10 & - & - & S.typhimurum & - \\
\hline Total & 50 & 5 & 5 & & 10 \\
\hline
\end{tabular}


Table 2: Biochemical reactions of suspected Salmonella isolates

\begin{tabular}{|l|l|}
\hline \multicolumn{1}{|c|}{ Test } & \\
\hline Catalase Result \\
\hline Oxidase & - ve \\
\hline Indol & $-\mathrm{ve}$ \\
\hline Methyl red & $+\mathrm{ve}$ \\
\hline Voges proskauer & $-\mathrm{ve}$ \\
\hline Citrate & $+\mathrm{ve}$ \\
\hline Urease & $-\mathrm{ve}$ \\
\hline TSI Bunt & \\
\hline \multicolumn{1}{|c|}{$\mathrm{H}_{2} \mathrm{~S}$} & Red \\
\hline \multicolumn{1}{|c|}{ Yellow } \\
\hline Sugar fermentation & $+\mathrm{ve}$ \\
\hline Dextrose & \\
\hline Lactose & + \\
\hline Sucrose & - \\
\hline Mannitol & - \\
\hline Maltose & + \\
\hline + positive & + \\
\hline
\end{tabular}

Table 3: Antibiotic sensitivity of isolated Salmonella

\begin{tabular}{|c|c|c|c|}
\hline \multirow{2}{*}{ Drugs } & \multicolumn{3}{|c|}{ Reactions } \\
\hline & Sensitive & Moderate & Resistant \\
\hline Neomycin (N $30 \mu \mathrm{g})$ & ++++ & & \\
\hline Gentamycin $(\mathrm{GM} 10 \mu \mathrm{g})$ & +++ & & \\
\hline Amoxycillin (AML $25 \mu \mathrm{g})$ & & & ++++ \\
\hline Norfloxacin (NOR $10 \mu \mathrm{g}$ ) & & +++ & \\
\hline Stryptomycin (S $10 \mu \mathrm{g})$ & & ++ & \\
\hline Ampicillin (AMB $40 \mu \mathrm{g})$ & & & ++++ \\
\hline Oxytetracyclin $(\mathrm{T} 30 \mu \mathrm{g})$ & & & ++++ \\
\hline Chloramphenicol $(\mathrm{C} 30 \mu \mathrm{g})$ & & +++ & \\
\hline Ceftiofur (CEF $30 \mu \mathrm{g})$ & ++++ & & \\
\hline Doxycilline (DO $30 \mu \mathrm{g}$ ) & & ++ & \\
\hline Erythromycin (E $15 \mu \mathrm{g})$ & & & ++++ \\
\hline
\end{tabular}

\section{DISCUSSION}

The incidence of salmonellosis has been increased as a major public health hazard (Rose et al., 1991). Contaminated poultry meat and eggs have been frequently implicated as sources for human Salmonella outbreaks in many countries (Humphrey 1999, Gast 1993, and Gast 2001). In the present work $5-7$ freshly dead or alive bird were collected from each one of 50 broiler chicken flocks to represent as a sample of 
the flock and were examined bacteriologically and serologically for isolation and identification of Salmonella. Results were tabulated (Table 1,2) indicating recognition of 5 Salmonella isolates and serotyped as Salmonella typhimurum. The relation between Salmonella infection and age of broiler flocks (50 flocks) was also investigated. The result revealed that 2 isolates of Salmonella typhimurum were recovered at the $2^{\text {nd }}$ week of age at a percent of $20 \%$, while 1 isolate as a percent of $10 \%$ was recovered at the $1^{\text {st }}, 3^{\text {rd }}$, and $4^{\text {th }}$ week of age. In Egypt, different Salmonella serotypes were isolated from broiler chicken as Salmonella typhimurum and Salmonella entritidis (Shahata, 1980 and Abd- Alla, 1991). Salmonella typhimurum was isolated by (Abd ElHamid et al., 1984) who examined 555 autopsied chicks and isolated Salmonella typhimurum in 26.1\%, Ibrahim and Abd El-Lateif (1997) recovered 7 Salmonella isolates which were identified as Salmonella typhimurum from diseased and dead baby chicks (5.6\%) while Hegazy (2002) examined 138 broiler flocks and found Salmonella typhimurum at a rate of $5.41 \%$. At the age of 5 weeks in 50 broiler flocks all samples were negative and non of the salmonellae were isolated which could be attributed to either large doses of antibiotics which were used till the $5^{\text {th }}$ week, or to the fact that Salmonella colonization of birds decreased with increasing broiler age. This idea was supported by Barnes et al., (1980), Williams (1984) and Rose et al. (1999). Since, one of the main purpose of such investigation is to find out the most suitable method for control, the antibiogram was carried out against Salmonella typhimurum isolate. The results showed that Salmonella was sensitive to Neomycin, Cetiofur and Gentamycin. However, they were moderately sensitive to Norfloxacin, Chloramphenicol and Doxycylin. Meanwhile, it was resistant to Amoxycillin, Ampicillin, Oxytetracyclin and Erythromycin. The high incidence of resistance could be attributed to the routein usage of subtherapeutic doses of antibiotics as feed additives to raise the feeding efficiency and the rate of weight gain. These findings were supported by Tourfrade (1984) and Coghlan (1991). Regardless of the different sensitivity patterns of Salmonella, the antibiogram is still the valied method for the drug of choice to control Salmonella infection. Abd El-Hamid et al., 1984, Heffernan, 1991 and Hegazy, 2002).

Identification of virulence of Salmonella isolates had led to better understanding of pathogenesis of diarrheal disease caused by them and providing a new dimension to their diagnosis. Our results showed that Salmonella isolate recovered from broiler chicken bind Congo red and pathogenic Salmonella have envolved some unique cellular products 
associatd with virulence of organism. Also, the result indicated that Salmonella isolate was hemolysin producer and this could be used as a phenotypic maker or virulence factor.

These results were supported and in agreement with Gorman and Adly (2004) and Sahar and Amany (2007).

\section{REFERANCES}

Abd-Allah, Mervat (1997): Studies on Salmonella microorganism in fowl in Fayoum Governorate. M.V.Sc Thesis, Fac. Vet. Med., Cairo University.

Abd-El-Hamid, H.S.; Ahmed, A.A.S.; Abou-El-AZM, I.M. and Safwat, E.E.A. (1984): Epidemiological studies on salmonellosis in Egyptian poultry. First Scientific Conference, Fac. Vet. Med. Assiut Univ., Egypt.

Abou-Zeed, Y.M.; Hariharan, H.; Poppe, C. and Kibengo, F.S.B. (2000): Characterization of Salmonella isolates from beef cattle, broiler chickens and human sources on Prince Edward Island. Comparative Immunology, Microbiology and Infectious Diseases, 23: 253-266.

Agenta, R.; Alison, N. and Bretifinal, Y. (1997): Marine salmonellosis studied by confocal microscopy Salmonella typhimurum and cytotoxic effect on phagocytes in vivo. J. EXP. Med., 186-4 (18): 569-580.

Barnes, E.M.; Impey, C.S. and Cooper, D.M. (1980): Manipulation of the crop and intestinal flora of the newly hatched chick. Am. J. Clin. Nutr., 33: 24-26.

Blackburn, C. Dew (1993): A review: Rapid and alternative methods for detection of salmonellosis in foods. J. Appl. Bacteriology., 75: 199-214.

Coghlan, A. (1996): Animals antibiotics treaten hospital epidemics. New scientist, 151: 7 .

Cohen, N.D.; Neibergs, H.L.; Wallis, D.E.; Simpson, R.B.; McGruder, E.D. and Hargis, B.M. (1994): Genus-specific detection of Salmonellae in equine feaces by use of the polymerase chain reaction. Amer. J. Vet. Res., 55: 1049-1054.

Cruickshank, R.; Duguid, J.P.; Marmian, B.P. and Swain, R.H.A. (1975): Medical Microbiol. Vol. 2, the practice of medical microbial. $12^{\text {th }}$ Ed ., Churchill livingstone, London. 
Douce, G.; Amine, I. and Strphen, J. (1991): Invasion of HEP2 cells by strain of Salmonella typhimurum of different virulence in relation to gastroenteritis. J. Med. Microbiol., 35: 349-257.

Finegold, S.M. and Martin, W.T. (1982): Diagnostic Microbiology. $6^{\text {th }}$ E.D., T.H Mosby Company, MSA.

Gast, R.K. (1993): Detection of Salmonella entritidis in experimentally infected laying hens by culturing pools of egg contents Poult. Sci., 72: 267-274.

Gast, R.K. (2001): The past, present and the future of Salmonella control in poultry. XII International Congress of the World Veterinary Poultry Association, Cairo, Egypt. 17-21 September.

Gorisman, E.A.; Chiae, E.; Lipps, C.J. and Hefferon, F. (1989): Salmonella typhimurum phop / phoQ virulence gene is a transcriptional regulator. Proc. Natl. Acad. Sci. USA, 86: 70777081 .

Gorman, R. and Adley, C. (2004): Characterization of Salmonella enterica serotype typhimurium isolates from human, food and animal source. J. Clinical Microbiology. 42 (5) 2314-2316.

Hartung, M. (1992): Salmonella entritidis and Salmonella typhimurum in Veterinarmedizinischen Salmonella isolation (1984-1991). Bundesgesundheitsblatt., 8: 383-388.

Heffernan, H.M. (1991): Antibiotic resistance among Salmonella from human and other sources in NewZeland. Epidemiol. Infect., 106 (1): 17-23.

Hegazy, A.E.H.M. (2002): Epidemiological studies on salmonellosis in chickens with special reference to Salmonella entritidis. Ph. D. Theses, Fac. Vet. Med. Alex. Univ. Egypt.

Humphery, T.J. (1999): Important and relevant attributes of the Salmonella organisms. Vet. Sci. Zootenica Int., May 48-51.

Ibrahim, Omyma, K. and Abd El-Latief, Ahlumel (1997): Studies on some bacterial agents isolated from dead - in - shell chicken embryos and baby chicks in Sharkia Province J. Egypt. Vet. Med. Ass., 57 (1): 747-763.

Kapperud, G.; Lasse, J.; Dommmarsnes, K.; Kristiansen, B.; Caugant, D.A.; Ask, E. and Jahkola, M. (1989): Comparasion of epidemiological marker method identification of Salmonella typhimurum isolates from an out break caused by contaminated chocolate. J. Clin. Microbiol. , 27: 2019-2024. 
Kauffmann, F. (1972): Serological diagnosis of Salmonella species Kauffmann - White Scheme. Minksgand, Copenhagen, Denmark.

Mayer, L.W. (1988): Use of plasmid profiles in epidemiologic surveillance of disease outbreaks and in tracing the transmission of antibiotic resistance. Clin. Microbiol. Rev., 1: 228-243.

Oxoid (1987): Manual of culture media, ingredients and other laboratory service. Wade Road, Basingtoke Hampshire, UK.

Quinn, P.J.; Carter, M.E.; Markey, B.K. and Carter, G.R. (1994): Clinical Veterinary Microbiology. Mosby Yearbook Europe Limited.

Rose, B.E.; Liabers, C.M. and Bennett, B. (1991): Evaluation of a colorimetric DNA hyberdization test for detection of Salmonella in meat and poultry products J. Food Prot., 54: 127-130.

Rose, N.; Beaudeau, F.; Drouin, P.; Toux, J.Y.; Rose, V. and Colin, P. (1999): Risk factors for Salmonella enterica subsp. Enterica contamination in French broiler chicken flocks at the end of the rearing period. Prev. Vet. Med., 39 (4): 265-277.

Sahar, R. Mohamed and Amany, N. Dapgh (2007): Bacteriological studies on Salmonella typhimurum isolated from different sources. J. Vet. Med., Giza 55, (2): 329-340.

Shahata, M.M. (1980): Some studies on paratyphoid infections in poultry in upper Egypt. Ph. D. Thesis, Fac. Vet. Med., Assiut Univ., Egypt.

Snoeyenbos, G.H. (1991): Pullorum disease. In diseases of poultry, $9^{\text {th }}$ Ed., Clanek, B.W.; Barnes, H.J.; Beard, C.W.; Reid, W.M. and Yoder, H.W. Jr. (eds.). Iowa State Univ. press, Ames. Iowa, pp. 73-86.

Tang, P.; Foubister, V.; Pucciarella, M. and Finally, B.B. (1993): Methods to study bacterial invasion. J. Micro. Biol. Method. 18: 227-240.

Tate, C.R.; Miller, R.G.; Mallinson, E.T.; Douglass, L.W. and Johnston, $R . W$. (1990): The isolation of Salmonella from poultry enviromental samples by several enrichment procedures using plating media with and without Novobiocin. Poult.Sci., 69(5): 721-726.

Tauxe, R. (1991): Salmonella: a post modern pathogen. J. Food Prot., 54 (7): 563-568. 
Tourfroda, A. (1984): Linking drugs to the dinner table antibiotics on the farm may be played a role in human disease Time, 124: 84.

Waltman, W.D.; Horne, A.M.; Pirkle, C. and Dickson, T.G. (1991): Use of delayed secondary enrichment for the isolation of Salmonella in poultry and poultry environments. Avian disease, 35 (1): 88-92.

Williams, J.E. (1984): Paratyphoid infection. In: Diseases of poultry $8^{\text {th }}$ Ed. Hofstand. M.S.; Barnes, H.J.; Calnek, B.W.; Reid, M.W and Yoder, H.W.; Jr (eds.) Iowa State Univ. Press. Ames, USA, PP. 91-129. 